\begin{tabular}{|c|c|c|}
\hline & $\begin{array}{l}\text { International Journal of Current Research in } \\
\text { Biosciences and Plant Biology }\end{array}$ & $=$ \\
\hline & Volume $\mathbf{7} \bullet$ Number 3 (March-2020) • ISSN: 2349-8080 (Online) & \\
\hline $\begin{array}{l}\text { EXCELLEN } \\
\text { PUBLISHERS }\end{array}$ & Journal homepage: $\underline{w w w . i j c r b p . c o m}$ & \\
\hline
\end{tabular}

\title{
Comparative study of tanniniferous shrubs as an alternative source of feed on performance of sheep vs. goats under semi-desert conditions of the north western-coast of Egypt
}

\author{
W. M. A. Sadek*, Elsaeed A. Elwakeel, Adel M. Saber, Lamiaa F. Abdel-Mawla, \\ Mohamed M. Anwar, H. Ghobashy and M. M. Eissa
}

Animal Production Research Institute, Agriculture Research Center (A.R.C), Dokki, Giza, Egypt

*Corresponding author; e-mail: wv_walid_wv@yahoo.com

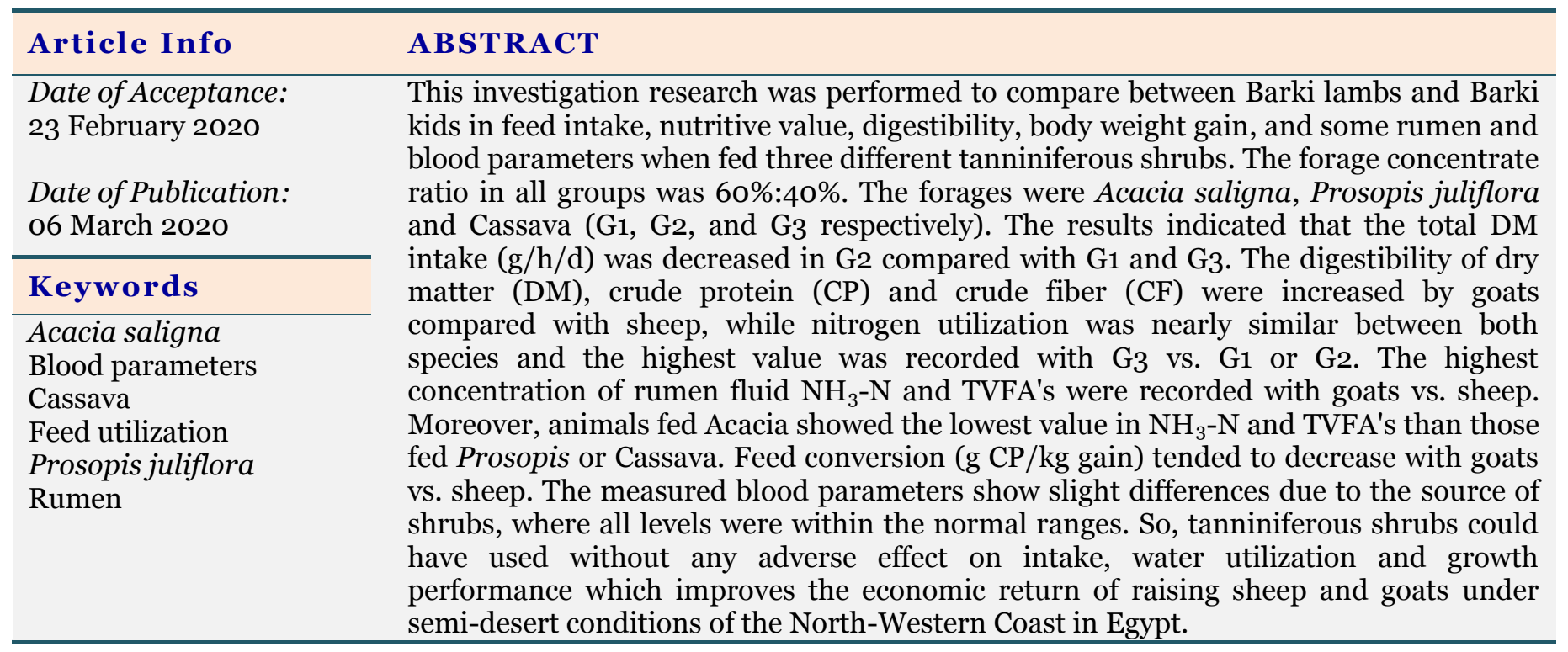

\section{Introduction}

Feed resources deficiency considers one of the basic constraints to improve animal production in arid and semi-arid regions of Egypt. Improving nutritional status of livestock grazing in desert (sheep, camels and goats), particularly during the prolonged dry seasons, could increase the average annual animal production by approximately $27 \%$ (El Shaer, 2004). Attention directed towards the necessity of utilizing the marginal resources, i.e. saline soils and underground water for producing unconventional animal feeds. The native natural rangelands constitute the principal feed resources in the Egyptian deserts. They are widely distributed throughout several regions of Egypt due to presence of numerous saline soils along the Mediterranean and Red Sea's shores. Halophytes represent a major part of the natural range, particularly perennials and shrubby ones. The less 
and unpalatable plant species represent approximately $70 \%$ of the total coverage (El Shaer, 2003). Several attempts made towards utilization of such low value or unpalatable halophytic plants through proper processing methods to improve their palatability and nutritional utilization. Under semi-arid area conditions, small ruminants fed on trees and shrubs such as Cassava and Acacia to solve the attendant problems of low productivity (El Shaer 2010 and Eissa et al., 2015a). However, such trees and shrubs foliage are generally rich in anti-nutritional factors, particularly tannins (Makkar, 2003). Feeding a mixture of these fodder shrubs could minimize or overcome the problems of palatability and toxic effects (Lowry, 1990; Yusran and Teleni, 2000; Anbarasu et al., 2001; Patra et al., 2002; El Shaer 2010; Eissa et al., 2015a and 2015b and Eissa et al., 2016). So, this work investigates the disparity Barki lambs and kids that using feeds consisted of legume shrubs and their reflections on feed intake, digestibility, nitrogen utilization, water consumption, growth performance, and some rumen and blood parameters under semi-arid conditions.

\section{Materials and methods}

The current study was carried out at Animal Production Research Station, Borg El Arab, belonging to Animal Production Research Institute, Agricultural Research Center, Egypt. This experiment aimed to investigate the effects of feeding three fodder legume trees of Acacia saligna, Prosopis juliflora and Cassava (leaves and twigs) on performance of Barki sheep and doe Barki goats.

\section{Location of the study}

This study was conducted at the Animal Production Research Station, Borg El Arab, stretches along $525 \mathrm{~km}$ on the Mediterranean Sea, west of Alexandria city latitudes $21^{\circ}$ and $31^{\circ}$ North and longitudes $25^{\circ}$ and $35^{\circ}$ East, the average temperature ranges from $13^{\circ} \mathrm{C}\left(56^{\circ} \mathrm{F}\right)$ in December and January to $26^{\circ} \mathrm{C}\left(79^{\circ} \mathrm{F}\right)$ in July and August.

\section{Preparation of fodder shrubs and chemical analysis}

The tree fodders, Acacia saligna, Prosopis and Cassava (leaves and twigs) were harvested along the sub-roads from the north western coast of
Egypt. The three fodder trees legumes were collected with heights of approximately 1.0-1.5 m and diameter of $0.5-2.5 \mathrm{~cm}$ and mechanically chopped into small pieces before introducing to animals. Samples from each herb species (up to $200 \mathrm{~g}$ ) were dried at $55^{\circ} \mathrm{C}$ for $48 \mathrm{~h}$ and ground to pass a $1 \mathrm{~mm}$ screen for subsequent chemical and In vitro analysis. Similarly, the pooled samples of the three fodders (Acacia saligna, Prosopis and Cassava (leaves and twigs)) that are immensely available in this area were selected for chemical analysis, dry matter (DM), ash, crude protein (CP), acid detergent fiber (ADF), neutral detergent fiber (NDF), and acid detergent lignin (ADL) of the rations (i.e., concentrate feed and saltbush ingredients) were analyzed using standard procedures (AOAC, 2000).

Total Nitrogen $(\mathrm{N})$ was determined by the microKjeldahl method (Pearson, 1976), while the crude protein was calculated by multiplying N\% by a factor of 6.25. Nitrogen free extract (NFE) was calculated by subtracting the sum of the percentages of protein, ash, ether extract and crude fiber from dry matter. Total ash content was determined by sample dry ashing at $550^{\circ} \mathrm{C}$ in a muffle furnace; the ash was dissolved in $10 \% \mathrm{HCl}$ and filtered (Oshodi, 1992).

\section{Experimental animals and treatments}

Eighteen Barki lambs averaged $12.56 \pm 0.61 \mathrm{Kg}$ body weight and eighteen Barki kids averaged $12.26 \pm 1.40 \mathrm{Kg}$ body weight were housed in a semi-roofed barn $4 \times 3 \times 5$ meters. Animals in the 3 groups were fed $2 \%$ of body weight concentrate feed mixture (CFM). Yet, three fodder legumes shrubs were fed ad-libitum. Conceding $1^{\text {st }}$ group (G1) of each species were fed Acacia saligna, $2^{\text {nd }}$ group (G2) of each species were fed Prosopis juliflora and $3^{\text {rd }}$ group $\left(\mathrm{G}_{3}\right)$ of each species were fed Cassava. The CFM was offered twice at 8 a.m. and 4 p.m. Drinking water was available all the times. Lambs and kids were weighed at the beginning then biweekly, the feeding experiment lasted 18 weeks (126 days).

\section{Experimental diets}

Treatment groups in both species were fed on the following diets to meet the NRC (1985) requirements as follow: 
(G1) $40 \% \mathrm{CFM}+60 \%$ Acacia saligna

(G2) 40\% CFM + 60 \% Prosopis juliflora

(G3) $40 \% \mathrm{CFM}+60 \%$ Cassava

\section{Digestibility trails}

Three digestibly trials were conducted using 9 rams and 9 bucks, three animals from each group were randomly chosen and used in digestibility trial to determine nutrients digestibility, nutritive value and nitrogen balance of the tested diets. Animals were housed in individual shaded pens $(1.0 \mathrm{~m} \times 1.25 \mathrm{~m})$ for 7 days before moving animals into metabolic cages to conduct the digestibility trial as adaptation period for animals, which gradually shifted from the station's ration to the experimental diets. Animals were placed in metabolic cages, weighted at the beginning and at the end of the digestibility trial, that lasted for 15 days of which the first 8 days were considered to adapt to metabolic cages and experimental diets, followed by another seven days as collection period. Daily feed intake of diets (difference between the offered feeds and refusals were daily weighed and recorded). Fecal output and urine were daily collected from each animal and kept for later analysis. Ten percent of each fecal sample was taken and dried at $65^{\circ} \mathrm{C}$ for a constant weight and ground to pass through a $1.0 \mathrm{~mm}$ mesh screen for chemical composition.

At the end of the trial, samples of rumen liquid were taken place after 4 hours of feeding to estimate $\mathrm{pH}$, rumen ammonia and volatile fatty acids. The samples were filtrated through three layers of gauze and directed to the determination of $\mathrm{pH}$ value. Ammonia nitrogen $\left(\mathrm{NH}_{3}-\mathrm{N}\right)$ concentration was measured according to Warner, (1964) and total volatile fatty acids (TVFA's) according to the technique described by Conway and O'Mally (1957).

\section{Blood samples}

Blood samples (10 $\mathrm{ml}$ ) were collected in nonheparinized tubes via the jugular vein from three lambs within each group once before feeding and at the end of the growing period at 8 a.m. Before collecting blood samples lambs were fasted $12 \mathrm{~h}$ (Tietz, 1987). Blood samples were centrifuged (at $4000 \mathrm{rpm}$ for $20 \mathrm{~min} / 5^{\circ} \mathrm{C}$ ). An aliquot of the separated serum was directed to enzymes activity determinations, while the other aliquot was stored frozen at $-20^{\circ} \mathrm{C}$ for subsequent biochemical analysis.

Total protein (TP) was determined according to (Gornal et al., 1949). On the other hand, albumin was determined according to (Doumas et al., 1971). Values of globulin were calculated by subtracting the value of albumin from the total protein. Concentrations of both alanine (ALT) and aspartate (AST) amino transferases were analyzed according to (Reitman and Frankel, 1957), Plasma urea-N and creatinine concentrations as indicators for kidney function were determined using bio diagnostic kits according to (Fawcett and Soctt, 1960) and (Schirmeister et al., 1964), respectively.

\section{Statistical analysis}

All data were analyzed by the GLM procedure of SAS (2003). Differences in mean values between treatments were compared by Duncan's multiple range test (1955).

\section{Results and discussion}

\section{Chemical composition}

The chemical compositions of different forages are presented in Table 1. It observed that CP content was noticeably higher with Cassava (22.94\%) than Prosopis juliflora (17.52\%) or Acacia saligna (15.66\%). While the highest value of $\mathrm{CF}$ and NFE (31.59 and 42.94\%, respectively) was recorded with Acacia saligna and the lowest values (28.05\% and $34.35 \%$, respectively) was detected with Cassava. The differences in DM and OM were of fewer values. The chemical composition obtained in present study is nearly similar to that obtained by Cloete et al. (1983), Ben Salem et al. (2005a), Fulkerson et al. (2008) and Shaker et al. (2014) on some salt tolerant fodder shrubs. The results showed that $\mathrm{CP}, \mathrm{EE}$ and ash contents were higher in tree legumes, while these tree legumes had higher $\mathrm{CP}, \mathrm{CF}, \mathrm{NFE}$ and OM\% which could be safe cover for the important nutrients requirements of animals (El-Shaer, 2010). Also (Salem et al., 2006) suggest that browse is potential as nitrogen supplements for ruminants fed low quality fodders through dry season in semi-arid regions. Moreover, shrubs and multipurpose trees has 
become a useful alternative ruminant feed in harsh semi-arid region (FAO, 1992; Topps, 1992; Eissa et al., 2015a and 2015b).

In addition, different studies suggested that the differences in their nutrient of forage legumes specially, CP and fiber content between these browse plants are probably due to sampling site, stage of plant growth and type (i.e., twigs, leaves or soft stem) of foliage sampled, season of collection, climatic influences soil type, fertility and water supply effect on nutrient concentrations in foliage growth (Ben Salem et al., 2005a; Abdel-Fattah 2005 and Salem et al., 2006). The $\mathrm{ADF}$ and NDF values were increased with Prosopis juliflora and Acacia saligna. Data is in agreement with results obtained by Horton (1981).

Table 1. Chemical composition of experimental feed (as \% on DM basis).

\begin{tabular}{|c|c|c|c|c|c|c|c|c|c|c|c|}
\hline \multirow[b]{2}{*}{ Item } & \multicolumn{7}{|c|}{ Chemical composition } & \multicolumn{4}{|c|}{ Fiber fraction } \\
\hline & DM & OM & $\mathrm{CP}$ & $\mathbf{C F}$ & $\mathbf{E E}$ & NFE & Ash & NDF & ADF & ADL & $\begin{array}{l}\text { CT } \\
\text { (g/kg DM) }\end{array}$ \\
\hline $\begin{array}{l}\text { Acacia } \\
\text { saligna }\end{array}$ & 93.45 & 91.66 & 15.66 & 31.59 & 1.47 & 42.94 & 8.34 & 60.86 & 54.57 & 48.96 & 25 \\
\hline $\begin{array}{l}\text { Prosopis } \\
\text { juliflora }\end{array}$ & 92.39 & $93 \cdot 30$ & $17 \cdot 52$ & 30.70 & 2.72 & 42.36 & 6.70 & $57 \cdot 41$ & 42.69 & 39.23 & 23 \\
\hline Cassava & $95 \cdot 39$ & 90.26 & 22.94 & 28.05 & 2.92 & $34 \cdot 35$ & 9.74 & $35 \cdot 49$ & 26.29 & 19.47 & 20 \\
\hline CFM & 91.20 & 91.20 & 15.70 & 14.23 & 3.13 & 60.84 & 6.10 & 43.00 & 17.30 & 5.8 & \\
\hline
\end{tabular}

\section{Digestion coefficients and nutritive values}

The obtained data in Table 2, Indicated that the goats had significantly $(\mathrm{P}<0.05)$ better digestion coefficients of DM, OM, CP, EE and NFE than sheep. The highest DM digestibility (54.54\%) was recorded with Cassava hay $\left(\mathrm{G}_{3}\right)$ followed by Acacia hay $(\mathrm{G} 1,49.16 \%)$, but the lowest values (36.97\%) were detected with Prosopis juliflora hay (G2) and the differences were significant $(\mathrm{P}<0.05)$. The same trend was observed also with $\mathrm{OM}, \mathrm{CP}$ and $\mathrm{CF}$ digestibility. But, the digestibility differences of EE and NFE were not significant. The presented values revealed that most nutrients digestibility of Cassava hay (G3) and Acacia saligna hay (G1) were better than the Prosopis juliflora hay. So, these results reflected on the nutritive values (Table 2) of Cassava hay and Acacia saligna with significant than Prosopis juliflora hay.

The obtained data of digestion was nearly similar with data obtained by (Salem et al., 2006; Agrawal et al., 2014). They reported that DM and CF digestibility were higher for goats than sheep probably reflecting their better capacity to detoxify secondary compounds in the rumen of goats vs. sheep (Silanikove et al., 1996). Moreover, higher digestibility of nutrients by goats may relate to many reasons like greater number of total protozoa in the rumen, total gut length in goats is lower and the retention time of digest in goats is higher than sheep (Santra et al., 1998). On the other hand, the lower values in digestibility of tree legumes mixture may be attributed to high content of tannins (Min et al., 2003; Mlambo et al., 2015). Tannins can reduce digestibility of crude protein and carbohydrate by inhibiting digestive enzymes and by altering permeability of the gut wall (Ortiz et al., 1993; Streeter et al., 1993).

\section{Feed Intake}

The average daily feed intake of growing lambs and kids are summarized in Table 3 . The daily DM intake tended to increase significantly $(\mathrm{P}<0.05)$ with G3 expressed as (550 g, $547 \mathrm{~g}$ or 52.59 $\mathrm{g} / \mathrm{kgw}^{0.75}, 53.47 \mathrm{~g} / \mathrm{kgw}^{0.75}$ ) for lambs and kids, respectively compared with the other groups. The lowest daily DM intake was recorded with G2 (516g or $\left.51.50 \mathrm{~g} / \mathrm{kgw}^{0.75}\right)$. The same trend was reported by Moujahed et al. (2005) who noted that DMI/ $\mathrm{kgw}^{0.75}$ was similar between sheep and goats when fed on Acacia cyanophylla as based diets (84.9 vs. 84.4 , respectively).

In many ways, researchers related differences in DMI in species and report that sheep consumed more DMI than goats (El Hag and Al Shargi, 1998; 
Salem et al., 2006). Contradictory, other studies reported that goats often eat more of some shrubs compared to sheep (Nefzaoui et al., 1993; Bartolom et al., 1998; Rogosic et al., 2006). The lower values of dry roughage intake might be attributing to high content of anti-nutritional factors such as tannins (Ben Salem and Smith, 2006). This agrees with the reports of Mau et al. (2006) who stated that goats secrete proline-rich proteins constantly while sheep only produce when consuming tannin rich plants. Tannin-binding proteins in the saliva might be responsible for minimizing tannin related negative effects by forming soluble protein tannin complexes (Bartolom et al., 1998) and these are considered to be counter-defenses acquired in the course of evolution by animals whose natural forage contains such tannins (Van Soest, 1991; Salem et al., 2006).

The increased total DMI observed in the supplemented goats is due to the fact that higher $\mathrm{CP}$ intake results in a large number of micro-flora in the rumen that can facilitate the digestibility of fibrous feed (Van Soest, 1991; Rogosic et al., 2006).

Table 2. Digestion coefficients and feeding values of rations fed to experimental animals.

\begin{tabular}{|c|c|c|c|c|c|c|c|c|c|}
\hline Item & & \multicolumn{6}{|c|}{ Digestion coefficients } & \multicolumn{2}{|c|}{ Feeding values } \\
\hline & G2 & $36.97^{c}$ & $37.91^{\mathrm{c}}$ & $39.49^{c}$ & $40.25^{c}$ & 52.44 & 47.01 & $40.73^{b}$ & $3.23^{c}$ \\
\hline SEM & & 1.02 & 1.24 & 1.07 & 1.10 & 0.81 & 1.10 & 1.22 & 0.04 \\
\hline Sign. & & * & * & * & $*$ & NS & NS & * & * \\
\hline Sheep & & 46.55 & $46.54^{b}$ & $45 \cdot 5^{6}$ & 43.77 & $54.13^{b}$ & $50.09^{b}$ & $42.74^{\mathrm{b}}$ & 3.89 \\
\hline SEM & & 0.94 & 1.10 & 1.01 & 1.05 & 0.73 & 0.69 & 1.13 & 0.24 \\
\hline Sign. & & NS & * & * & $\mathrm{NS}$ & * & * & * & NS \\
\hline Sheep & G1 & $47 \cdot 71$ & 48.41 & 42.54 & 41.78 & 55.83 & 51.58 & 44.07 & 3.68 \\
\hline & G2 & 36.62 & 37.07 & 38.84 & 40.25 & 51.92 & $45 \cdot 47$ & 39.69 & 3.10 \\
\hline & G3 & $55 \cdot 31$ & 54.13 & 55.29 & 49.28 & 54.63 & 53.21 & 44.45 & 4.89 \\
\hline Goats & G1 & 50.60 & 50.96 & 44.25 & 41.58 & 57.65 & 58.47 & 48.11 & 3.83 \\
\hline
\end{tabular}

(G1) 40\% CFM + 60\% Acacia saligna, (G2) 40\% CFM + 60\% Prosopis juliflora, (G3) 40\% CFM + 60\% Cassava; a- c: Means in the same column with different letters are significantly $(\mathrm{P}<0.05)$ different. NS: Non-significant.

Table 3. Daily dry matter intake by experimental animals.

\begin{tabular}{|c|c|c|c|c|}
\hline Item & G1 & G2 & G3 & SEM \\
\hline \multicolumn{5}{|c|}{ Daily feed intake by sheep during experimental period (DMI, g/h/d) } \\
\hline CFM (C) & 223 & 216 & 227 & 0.54 \\
\hline Roughage (R) & $315^{\mathrm{b}}$ & $300^{c}$ & $323^{\mathrm{a}}$ & 1.53 \\
\hline Total DMI (g/h/d) & $538^{\mathrm{b}}$ & $516^{c}$ & $550^{\mathrm{a}}$ & 1.14 \\
\hline DMI (g/kgwº.75) & 52.49 & 51.50 & 52.59 & 1.02 \\
\hline $\mathrm{R} / \mathrm{C}$ ratio & $59: 41$ & $58: 42$ & $59: 41$ & \\
\hline \multicolumn{5}{|c|}{ Daily feed intake by goats during experimental period (DMI, g/h/d) } \\
\hline CFM & 220 & 205 & 222 & 0.81 \\
\hline Roughage & $319^{b}$ & $308^{c}$ & $325^{\mathrm{a}}$ & 1.32 \\
\hline Total DMI (g/h/d) & $539^{\mathrm{b}}$ & $513^{c}$ & $547^{\mathrm{a}}$ & 1.10 \\
\hline $\mathrm{DMI}\left(\mathrm{g} / \mathrm{kgw}^{0.75}\right)$ & 53.10 & 52.07 & 53.47 & 0.95 \\
\hline $\mathrm{R} / \mathrm{C}$ ratio & $59: 41$ & $60: 40$ & $59: 41$ & \\
\hline
\end{tabular}

(G1) 40\% CFM + 60\% Acacia saligna, (G2) 40\% CFM + 60\% Prosopis juliflora, (G3) 40\% CFM + 60\% Cassava; a- c: Means at the same row with different superscripts are significantly different at $\mathrm{P}<0.05$. 


\section{Water and nitrogen utilization}

As presented in Table 4, the free water consumed was higher by lambs and kids fed Cassava (G3) 1.930 and $1.873 \mathrm{~L} / \mathrm{d}$, respectively compared with the other groups (Table 4$)$. The highest $(\mathrm{P}<0.05)$ value of daily water intake was recorded with $\mathrm{G} 3$ lambs $(1.960 \mathrm{~L}$ or $\left.188 \mathrm{ml} / \mathrm{kgw}^{0.75}\right)$, while with kids it was $(1.903 \mathrm{~L}$ or $\left.186 \mathrm{ml} / \mathrm{kgw}^{0.75}\right)$. Animals in $\mathrm{G} 2$ recorded the lowest value $(\mathrm{P}<0.05)$ with lambs $(1.845 \mathrm{ml}$ or 184 $\left.\mathrm{ml} / \mathrm{kgw}^{0.75}\right)$, while kids recorded $(1.780 \mathrm{~L}$ or 185 $\left.\mathrm{ml} / \mathrm{kgw}^{0.75}\right)$. Water consumption $(\mathrm{ml} / \mathrm{kg}$ feed consumed) increased as water intake by lambs vs. kids and with G3 compared with other groups. Water loss via the urine is significantly $(\mathrm{P}<0.05)$ higher in G3 (animals fed Cassava) than other treatment groups, and this considered as a reflection of higher water intake by these animals. Free access to water also produces higher loss of water due to metabolism, respiration and insensible loss (Table 4). The obtained data of water efficiency calculated in $\mathrm{ml} / \mathrm{kg} \mathrm{BW}^{0.75}$ was nearly similar between two species and among all groups. The goat groups are shown to be more efficient in the use of water.

Table 4. Water and nitrogen utilization by experimental animals fed some legumes shrubs.

\begin{tabular}{|c|c|c|c|c|c|c|c|c|}
\hline \multirow{2}{*}{ Item } & \multicolumn{4}{|l|}{ Sheep } & \multicolumn{4}{|l|}{ Goats } \\
\hline & G1 & G2 & G3 & SEM & G1 & G2 & G3 & SEM \\
\hline \multicolumn{9}{|c|}{ Water utilization } \\
\hline \multicolumn{9}{|l|}{ Intake } \\
\hline Free water $\mathrm{L} / \mathrm{h} / \mathrm{d}$ & $1.890^{\mathrm{b}}$ & $1.805^{\mathrm{c}}$ & $1.930^{\mathrm{a}}$ & 0.15 & $1.837^{\mathrm{b}}$ & $1.740^{c}$ & $1.873^{\mathrm{a}}$ & 0.22 \\
\hline$\%$ of total intake & 97.93 & 97.83 & 98.45 & & 97.87 & 97.75 & 98.42 & \\
\hline Feed water $\mathrm{L} / \mathrm{h} / \mathrm{d}$ & 0.04 & 0.04 & 0.03 & 0.01 & 0.04 & 0.04 & 0.03 & 0.01 \\
\hline$\%$ of total intake & 2.07 & 2.17 & 1.55 & & 2.13 & 2.25 & 1.58 & \\
\hline Total water intake (L/d) & $1.930^{\mathrm{b}}$ & $1.845^{\mathrm{c}}$ & $1.960^{\mathrm{a}}$ & 0.05 & $1.877^{\mathrm{b}}$ & $1.780^{c}$ & $1.903^{\mathrm{a}}$ & 0.05 \\
\hline \multicolumn{9}{|l|}{ Output } \\
\hline Urine $(\mathrm{L} / \mathrm{d})$ & $1.100^{\mathrm{b}}$ & $1.000^{\mathrm{b}}$ & $1.140^{\mathrm{a}}$ & 0.10 & $0.998^{\mathrm{b}}$ & $0.938^{b}$ & $1.044^{\mathrm{a}}$ & 0.11 \\
\hline$\%$ of total intake & 57.00 & 54.20 & 58.16 & & 53.15 & 52.70 & 54.87 & \\
\hline Faecal water $(\mathrm{L} / \mathrm{d})$ & $0.536^{\mathrm{a}}$ & $0.545^{\mathrm{a}}$ & $0.454^{b}$ & 0.09 & $0.395^{b}$ & $0.431^{b}$ & $0.485^{\mathrm{a}}$ & 0.14 \\
\hline$\%$ of total intake & 27.77 & 29.54 & 32.14 & & 21.04 & 24.16 & 25.49 & \\
\hline Unmeasured water (L/d) & $0.294^{b}$ & $0.300^{\mathrm{a}}$ & $0.190^{c}$ & 0.09 & $0.484^{\mathrm{a}}$ & $0.412^{\mathrm{b}}$ & $0.374^{c}$ & 0.11 \\
\hline$\%$ of total intake & 15.23 & 16.26 & 9.70 & & 25.81 & 23.14 & 19.64 & \\
\hline Total water loss (L/d) & $1.930^{\mathrm{b}}$ & $1.845^{\mathrm{c}}$ & $1.960^{\mathrm{a}}$ & 0.05 & $1.877^{\mathrm{b}}$ & $1.781^{\mathrm{c}}$ & $1.903^{\mathrm{a}}$ & 0.05 \\
\hline Water efficiency $\left(\mathrm{ml} / \mathrm{kgw}^{0.75}\right)$ & 188 & 184 & 188 & & 185 & 185 & 186 & \\
\hline $\mathrm{ml} / \mathrm{g}$ DM intake & 3.59 & 3.58 & 3.56 & & 3.48 & 3.47 & 3.48 & \\
\hline \multicolumn{9}{|c|}{ Nitrogen utilization } \\
\hline Intake & & & & & & & & \\
\hline N-consumed $(\mathrm{g} / \mathrm{d})$ & $13 \cdot 37^{\mathrm{b}}$ & $13.8^{\mathrm{c}}$ & $17.52^{\mathrm{a}}$ & 0.08 & $13.49^{\mathrm{b}}$ & $13.78^{c}$ & $17.5 \mathrm{O}^{\mathrm{a}}$ & 0.09 \\
\hline \multicolumn{9}{|l|}{ Output } \\
\hline Faecal-N (g/d) & $7.68^{a}$ & $6.46^{b}$ & $7.80^{\mathrm{a}}$ & 0.11 & $6.32^{\mathrm{b}}$ & $6.40^{\mathrm{b}}$ & $8.66^{a}$ & 0.11 \\
\hline Urine-N & $2.69^{\mathrm{a}}$ & $1.90^{\mathrm{b}}$ & $3.01^{\mathrm{a}}$ & 0.10 & $1.18^{\mathrm{b}}$ & $1.01^{\mathrm{b}}$ & $2.53^{\mathrm{a}}$ & 0.08 \\
\hline Retention (Intake - excretion) & $3.00^{b}$ & $5.48^{c}$ & $6.71^{\mathrm{a}}$ & 0.12 & $5.99^{\mathrm{b}}$ & $6.37^{\mathrm{a}}$ & $6.31^{\mathrm{a}}$ & 0.14 \\
\hline
\end{tabular}

(G1) 40\% CFM + 60\% Acacia saligna, (G2) 40\% CFM + 60\% Prosopis juliflora, (G3) 40\% CFM + 60\% Cassava; a-c: Means at the same row with different superscripts are significantly different at $\mathrm{P}<0.05$.

The values of total water loss in this study are nearly similar to those obtained by Ahmed et al. (2009) on growing Rahmani lambs (ranged from 1.90 to $3.16 \mathrm{ml} / \mathrm{g} \mathrm{DM}$ intake) and Soliman et al. (2010) on growing Zaraibi goats (ranged from 2.22 to $3.30 \mathrm{ml} / \mathrm{g} \mathrm{DM}$ intake).

In corroboration with previous findings by Aganga (1992) studied the water use by sheep and goats in the North of Nigeria and observed significant $(\mathrm{P}<0.05)$ differences on several variables, such as water intake, expressed in $\mathrm{L} / \mathrm{kg}$ of metabolic weight, that was higher in sheep than goats. Lower water intake by goats has been observed when compared to sheep and other animals, because of the adaptation process of goats to situations of limited water availability. The adaptation is similar to camels, known for their ability to withstand long 
periods without water (Silanikove, 2000) and their greater ability to reduce water loss through evaporation and feces and to concentrate urine (Robertshaw, 1982). Similarly, Alves et al. (2007) in a study conducted in the municipality of Petrolia, Pernambuco state, reported that sheep ingested higher amount of water than goats.

Table 4 shows that the goats groups retain higher quantity of nitrogen while lambs' loose consumed nitrogen rather than being retained. Ben Salem et al. (1997) reported that, the decline in nitrogen retention of animals fed tree legumes mixture $v s$. alfalfa hay might be due to the lack of soluble nitrogen or low digestibility in the basal diets and high tannins concentrations in browse species which associated with reduced nitrogen retention. Conversely, diets high in condensed tannins can also increase post-ruminal absorption of nitrogen (Egea et al., 2016), decrease in fecal nitrogen excretion (Ndemanisho et al., 1997) and increase $\mathrm{N}$ retention (Foroughbakhch et al., 2013).

\section{Rumen parameters}

The $\mathrm{pH}$, ammonia nitrogen $\left(\mathrm{NH}_{3}-\mathrm{N}, \mathrm{mg} / 100 \mathrm{ml}\right.$ $\mathrm{RL}$ ) and total volatile fatty acids (VFA's, mg / 100 $\mathrm{ml} \mathrm{RL)} \mathrm{concentrations} \mathrm{are} \mathrm{presented} \mathrm{in} \mathrm{Table} 5$. The $\mathrm{pH}$ values ranged from 6.38 to 6.48 for all studied groups. Rumen $\mathrm{NH}_{3}-\mathrm{N}$ and TVFA's significantly increased in $\mathrm{G}_{3}$, while the lowest values were determined in the G1. These results may be attributed to the low content of tannin in G3. Narjisse et al. (1995) reported that rumen ammonia was depressed $(\mathrm{P}<0.05)$ by tannin infusion in sheep. Muller et al. (1989) found that reduction of ruminal $\mathrm{NH}_{3}-\mathrm{N}$ and TVFA's concentration by saponins were due partly to defaunation. Cheeke (2000) found that saponins have pronounced antiprotozoal activity.

Table 5. Some rumen liquor parameters concentrations of sheep and goats fed on legumes trees.

\begin{tabular}{|c|c|c|c|c|}
\hline \multirow[b]{2}{*}{ Item } & & \multicolumn{3}{|c|}{ Rumen liquor parameters } \\
\hline & & pH & $\begin{array}{l}\mathrm{NH}_{3}-\mathrm{N} \\
(\mathrm{mg} / 100 \mathrm{ml} \mathrm{RL})\end{array}$ & $\begin{array}{l}\text { TVFA's } \\
\text { (mg/100 ml RL) }\end{array}$ \\
\hline & G1 & 6.48 & $20.75^{\mathrm{c}}$ & $11.95^{\mathrm{c}}$ \\
\hline & G2 & 6.45 & $21.50^{\mathrm{b}}$ & $12.05^{\mathrm{b}}$ \\
\hline & $\mathrm{G}_{3}$ & 6.38 & $22.75^{\mathrm{a}}$ & $12.70^{\mathrm{a}}$ \\
\hline \multicolumn{2}{|l|}{ SEM } & 0.06 & 0.68 & 0.78 \\
\hline \multicolumn{2}{|l|}{ Sign. } & NS & $*$ & $*$ \\
\hline \multicolumn{2}{|l|}{ Sheep } & 6.44 & $21.36^{\mathrm{b}}$ & $11.70^{\mathrm{b}}$ \\
\hline \multicolumn{2}{|l|}{ Goats } & 6.43 & $21.97^{\mathrm{a}}$ & $12.77^{\mathrm{a}}$ \\
\hline \multicolumn{2}{|l|}{ SEM } & 0.04 & 0.39 & 0.25 \\
\hline \multirow[t]{2}{*}{ Sign. } & & NS & & \\
\hline & G1 & 6.47 & 20.39 & 11.60 \\
\hline \multirow[t]{3}{*}{ Sheep } & G2 & 6.46 & 21.20 & 11.30 \\
\hline & G3 & 6.38 & 22.50 & 12.20 \\
\hline & G1 & 6.48 & 21.10 & 12.30 \\
\hline \multirow[t]{2}{*}{ Goats } & G2 & 6.43 & 21.80 & 12.80 \\
\hline & G3 & 6.37 & 23.00 & 13.20 \\
\hline SEM & & 0.08 & 1.10 & 1.13 \\
\hline Sign. & & NS & NS & NS \\
\hline
\end{tabular}

Goats were slightly significantly $(\mathrm{P}<0.05)$ higher in ruminal $\mathrm{NH}_{3}-\mathrm{N}$ and TVFA's than sheep (21.97 vs. $21.36 \mathrm{mg} / 100 \mathrm{ml}$ and 12.77 vs. $11.70 \mathrm{mg} / 100 \mathrm{ml}$, respectively) and were lower $(\mathrm{P}<0.05)$ for animals fed G1 vs. G2 or G3. Domingue et al. (1991) who indicated that goats were considered to have a higher concentration of rumen ammonia, which could lead to an improved fiber digestion. However, animals fed Cassava (G3) showed higher $(\mathrm{P}<0.05) \mathrm{NH}_{3}-\mathrm{N}$ than those fed Acacia (G1) or Prosopis (G2). Lower concentrations of $\mathrm{NH}_{3}-\mathrm{N}$ in rumen fluid found with $\mathrm{G} 1$ could be attributed to the inhibition of rumen protein degradation and deamination processes by condensed tannins (Mc 
Sweeney et al., 2001; Szumacher-Strabel and Cieślak 2010; Carro et al., 2012). The low concentrations of ruminal TVFA's in rumen could be attributed to the reduce energy supply to the host (Aschenbach et al., 2012). Thus, reduction in ruminal protozoa numbers observed when saponins fed (Klita et al., 1996) or within in vitro ruminal fermentation system (Wang et al., 1998). It caused by reaction of saponins with cholesterol in the protozoal cell membrane, causing break down of the membrane cell lysis and death.

\section{Growth performance, feed and economic efficiencies}

Growth performance and feed efficiency of Barki lambs and Barki kids fed experimental rations were presented in (Table 6). Results showed wide range of dietary concentrations of the condensed tannin (CT) ranged from 20 to $25 \mathrm{~g} / \mathrm{kg} \mathrm{DM}$ (Table 1) which reflected on the improved daily weight gain of Barki lambs and Barki kids on temperate fresh forages. Values of body weight change significantly $(\mathrm{P}<0.05)$ between both species and feeding treatments. The obtained results revealed significant $(\mathrm{P}<0.05)$ differences among groups fed different rations in final body weight, total body gain and daily body gain. The highest values recorded with $\mathrm{G}_{3}$ (33.46 and $32.42 \mathrm{~kg}$ for lambs and kids, respectively), while the lowest values were detected with G2 (31.19 and $28.70 \mathrm{~kg}$, for lambs and kids, respectively). This improvement could be attributed to the increase in dry matter intake (DMI, g/h/d) in G3 (Table 3) compared with the other groups. The obtained results showed that values of body weight changed significantly $(\mathrm{P}<0.05)$ between both species and feeding treatments. This disagreement with finding of (Brown et al., 2017) who reported that final body weight where similar in goats fed a diet contained 50\% of dietary Acacia karroo compared with other treatment groups.

Table 6. Growth performance, feed conversion and economic efficiency of Barki sheep and goats fed some legume shrubs.

\begin{tabular}{|c|c|c|c|c|c|c|}
\hline \multirow{2}{*}{ Item } & \multicolumn{3}{|l|}{ Sheep } & \multicolumn{3}{|l|}{ Goat } \\
\hline & G1 & G2 & G3 & G1 & G2 & G3 \\
\hline No. of lambs & 5 & 5 & 5 & 5 & 5 & 5 \\
\hline Feeding period (weeks) & 18 & 18 & 18 & 18 & 18 & 18 \\
\hline Initial weight $(\mathrm{kg})$ & $12.32 \pm 0.29$ & $12.02 \pm 0.06$ & $12.08 \pm 0.46$ & $12.28 \pm 0.11$ & $12.32 \pm 0.29$ & $12.02 \pm 0.06$ \\
\hline Final weight (kg) & $32.23 \pm 0.46^{b}$ & $31.19 \pm 0.53^{c}$ & $33.46 \pm 0.48^{\mathrm{a}}$ & $31.66 \pm 0.48^{\mathrm{a}}$ & $28.70 \pm 0.46^{b}$ & $32.42 \pm 0.53^{\mathrm{a}}$ \\
\hline Total gain $(\mathrm{kg})$ & $19.91 \pm 0.32^{\mathrm{a}}$ & $19.17 \pm 0.53^{\mathrm{a}}$ & $21.38 \pm 0.13^{b}$ & $19.38 \pm 0.42^{\mathrm{a}}$ & $16.38 \pm 0.32^{\mathrm{b}}$ & $20.40 \pm 0.53^{a}$ \\
\hline Daily body gain (g) & $158 \pm 0.003^{a}$ & $152 \pm 0.004^{b}$ & $170 \pm 0.001^{c}$ & $154 \pm 0.003^{a}$ & $130 \pm 0.003^{b}$ & $162 \pm 0.004^{\mathrm{a}}$ \\
\hline $\begin{array}{l}\text { Feed conversion } \\
\text { (g CP/kg gain) }\end{array}$ & 187 & 176 & 155 & 182 & 151 & 148 \\
\hline \multicolumn{7}{|c|}{ Economic efficiency } \\
\hline $\begin{array}{l}\text { Total feed coast } \\
\text { (as feed)/h/d (L.E.) }\end{array}$ & 1.30 & 1.25 & 1.31 & 1.28 & 1.20 & 1.29 \\
\hline Price of daily gain (L.E.) & 4.47 & 4.56 & 5.10 & 4.62 & 3.90 & 4.86 \\
\hline Efficiency (\%) & 3.44 & 3.64 & 3.89 & 3.61 & 3.25 & 3.77 \\
\hline \multicolumn{7}{|c|}{ 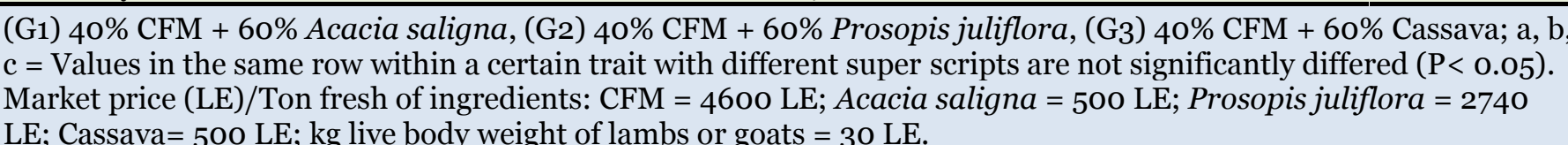 } \\
\hline
\end{tabular}

With respect to ruminant nutrition, specific levels of tannins consider of beneficial effect including better utilization of dietary protein, faster body weight or wool growth, higher milk yield, increased fertility and improved animal welfare and health through the prevention of bloat and reduced worm burdens (Mueller-Harvey 2006).
Aganga and Tshwenyane (2003) reported that the average daily gain was slightly higher with significant increase in feed intake and feed conversion ratio for Tswana goats fed forage legumes tree as supplement. This effect was ascribed to increase levels of post-rumen available proteins (Barry and McNabb 1999; Barry et al., 
2001; Ben Salem et al., 2003; Gemeda and Hassen 2015; Eissa et al., 2015a and 2015b).

Data in Table 6 indicates that the economic efficiency (EE) was better with G3 (Cassava) compared with the other groups, in terms of growth performance of the offspring (lambs or kids) in relation to treatments. Feed conversion ( $\mathrm{g}$ $\mathrm{CP} / \mathrm{kg}$ gain) tended to decrease with goats vs. sheep may be due to reduced voluntary feed intake (as shown in Table 3) accompanying by inadequate drinking led to decreased nitrogen consumption by the goat groups (Table 4), since the main source of nitrogen intake by the goats is feed. Correspondingly, the total amount of nitrogen excreted decreased as the water supply to the animals reduces compared with sheep groups. Thus, the slightly increase of economic efficiency was detected with $\mathrm{G}_{3}$ (3.89 and 3.77\% for lambs and kids, respectively). In this respect, Eissa et al. (2015a, 2015b and 2016) found that economic efficiency was greatly improved with substitution of legumes trees with ammoniated wheat straw in sheep rations. Our tree legumes mixture recorded a reduction in feed cost of $\mathrm{Kgw}^{0.75}$ about $53 \%$ for sheep and $54 \%$ for goats compared with control group due to the low price of tree legumes mixture compared with alfalfa. The results are in agreement with those reported by (Fayed et al., 2001; Mousa and El-Shabrawy, 2003 and Mehrez et al., 2011) who found that the feed cost was relatively lower than the control when sheep and goats fed rations contained 30-40\% Acacia.

\section{Blood parameters}

Data of blood parameters shown in Table 7 reveals that the lowest concentrations of total proteins (TP), albumin (AL) and globulin (GL) were detected with G1. These findings are in accordance with those reported by Eissa et al. (2016). This reduction of TP in animals fed salt shrubs might be owing to the high content of tannins in these plants. In agreement, Muller et al. (1989) and Reed et al. (1990) since they reported that high content of tannins in Acacia probably decreases the digestibility of crude protein. Coles (1986) found that poor absorption of dietary constituents from the intestinal tract leads to hypoproteinemia. Mahmoud (2001) reported that the decrease in concentration of globulin in sheep might be due to the presence of high level of tannins which form complexes with diet.

Table 7. Effect of feeding experimental rations on some blood serum parameters of the experimental animals.

\begin{tabular}{lllllllll}
\hline \multirow{2}{*}{ Item } & Sheep & \multicolumn{7}{c}{ Goats } \\
\cline { 2 - 9 } & G1 & G2 & G3 & SEM & G1 & G2 & G3 & SEM \\
\hline Total protein, g/dl & $6.45^{\mathrm{b}}$ & $7.10^{\mathrm{a}}$ & $7.16^{\mathrm{a}}$ & 0.32 & $6.55^{\mathrm{b}}$ & $6.82^{\mathrm{b}}$ & $7.21^{\mathrm{a}}$ & 0.51 \\
Albumin(A), g/dl & $3.63^{\mathrm{b}}$ & $3.87^{\mathrm{a}}$ & $3.90^{\mathrm{a}}$ & 0.11 & $3.70^{\mathrm{b}}$ & $3.94^{\mathrm{b}}$ & $4.11^{\mathrm{a}}$ & 0.11 \\
Globulin(G), g/dl & $2.82^{\mathrm{b}}$ & $3.23^{\mathrm{a}}$ & $3.26^{\mathrm{a}}$ & 0.10 & $2.85^{\mathrm{b}}$ & $2.88^{\mathrm{b}}$ & $3.10^{\mathrm{a}}$ & 0.08 \\
Urea-N, mg/dl & $22.10^{\mathrm{b}}$ & $22.13^{\mathrm{ab}}$ & $23.19^{\mathrm{a}}$ & 0.08 & $21.50^{\mathrm{b}}$ & $22.62^{\mathrm{ab}}$ & $23 . \mathrm{O}^{\mathrm{a}}$ & 0.42 \\
Creatinine mg/dl & 1.40 & 1.38 & 1.37 & 0.14 & 1.25 & 1.27 & 1.23 & 0.10 \\
AST, u/l & 30.44 & 30.10 & 30.15 & 0.52 & 30.18 & 31.05 & 30.48 & 0.54 \\
ALT, u/l & $17.96^{\mathrm{a}}$ & $16.11^{\mathrm{b}}$ & $16.20^{\mathrm{b}}$ & 0.43 & $17.94^{\mathrm{a}}$ & $17.98^{\mathrm{a}}$ & $16.90^{\mathrm{b}}$ & 0.36 \\
\hline
\end{tabular}

(G1) 40\% CFM + 60\% Acacia saligna, (G2) 40\% CFM + 60\% Prosopis juliflora, (G3) 40\% CFM + 60\% Cassava; a- c: Means at the same row with different superscripts are significantly different at $\mathrm{P}<0.05$.

Thus, the higher concentrations of total proteins (TP), albumin (AL) and globulin (GL) in G3 than G1 and G2 might be owing to $\mathrm{N}$ concentration. The same trend was found in blood urea-N concentration (mg/dl). Generally, this can be attributed to the high protein content in cassava shrubs, which is utilized efficiently by rumen microflora (Shaker et al., 2014). Concentrations of enzymes aspartate amino transferase (AST) and alanine amino transferase (ALT) that, conventionally used for diagnosing hepatic damage, were higher with salt tolerant shrubs groups but the differences were significant (P) for ALT concentration only. Generally, the obtained results indicate that blood components measured showed slight differences due to source of shrubs, where all levels were within the normal ranges reported by Kaneko (1989).

Moreover, sheep had slightly insignificant higher concentrations of overall urea and creatinine than 
goats with insignificant effect among experimental diets. These findings were in harmony with those reported by Mehrez et al. (2011) who found that animals fed mixture of sun-dried Acacia, Prosopis and Leucaena showed lower mean concentration of urea and creatinine compared with control group. At the same trend, goats recorded insignificant higher values of overall AST and ALT compared to sheep. The results were in agreement with Mehrez et al. (2011). In general, the increase of ALT or AST activity might be caused by high tannins (Shaker et al., 2008).

\section{Conclusion}

In brief, the obtained results proved that using sun-dried chopped Acacia, Prosopis, and Cassava as non-traditional feed have been used without having any adverse effect on intake, water utilization and growth performance which improves the economic return of raising sheep and goats under semi-desert conditions of North Western Coast in Egypt.

\section{Conflict of interest statement}

Authors declare that they have no conflict of interest.

\section{References}

A. O. A. C., 2000. Official Methods of Analysis. $16^{\text {th }}$ Edn. Association Analytical Chemists, Washington, D.C., USA.

Aganga, A. A., 1992. Water utilization by sheep and goats in northern Nigeria. Rev. Mund. Zootec. 73,4 .

Aganga, A.A., Tshwenyane, S. O., 2003. Feeding values and anti-nutritive factors of forage tree legumes. Pak. J. Nutr. 2(3), 170-177.

Agrawal, A. R., Karim, S. A., Rajiv Kumar, Sahoo, A., John, P. J., 2014. Sheep and goat production: Basic differences, impact on climate and molecular tools for rumen microbiome study. Int. J. Curr. Microbiol. App. Sci. 3(1), 684-706.

Ahmed, M. E., Shehata, E. I., Abou Ammou, F. F., Khalifa, E. I., EL-Zolaky, O. A., 2009. Productive and reproductive performance of Rahmani sheep fed rations containing reed forage (Arundo domax L.) either fresh, hay or silage. Egypt. J. Sheep Goat Sci. 4(1), 45-54.
Alves, J. M., Araújo, G. G. L., Porto, E. P., 2007. Feno de erva-sal (Atriplex nummularia Lindl.) e palma-forrageira (Opuntia ficus Mill.) em dietas para caprinos e ovinos. Rev. Cient. Prod. Anim. 9(1), 43-52.

Anbarasu, C., Dutta, N., Sharma, K., 2001. Use of leaf meal mixture as a protein supplement in the ration of goats fed wheat straw. Anim. Nutr. Feed Technol. 1, 113-123.

Aschenbach, J. R., Zebeli, Q., Tafaj, M., Boguhn, J., Ametaj, B. N., Drochner, W., 2012. Changes in ruminal volatile fatty acid production and absorption rate during the dry period and early lactation as affected by rate of increase of concentrate allowance J. Dairy Sci. 95(3), 10411056.

Barry, T. N., McNabb, W. C., 1999. The implications of condensed tannins on the nutritive value of temperate forages fed to ruminants. Brit. J. Nutr. 81, 263-272.

Barry, T. N., McNeill, D. M., McNabb, W. C., 2001. Plant secondary compounds: their impact on forage nutritive value and upon animal production. In: Proceedings of the XIX International Grassland Congress, São Pedro, São Paulo, Brazil, Feb. 11-21. pp.445-452.

Bartolom'e, J., Franch, J., Plaixats, J., Seligman, N. G., 1998. Diet selection by sheep and goats on Mediterranean heath woodland range. J. Range Manage. 51, 383-391.

Ben Salem, H., Ben Salem, I., Nefzaoui, N., Ben Saïd, M. S., 2003. Effects of PEG and olive cake feed blocks supply on feed intake, digestion, and health of goats given kermes oak (Quercus coccifera L.) foliage. Anim. Feed Sci. Technol. 110, 45-59.

Ben Salem, H., Nefzaoui, A., Ben Salemm L., Tisserand, J. L., 1997. Intake, digestibility in sheep given fresh or air-dried Acacia cynophylla Lindl. foliage. Ann. Zootech, 46, 361-374.

Ben Salem, H., Nefzaoui, A., Makkar, H., Hochlef, H., Ben Salem, I., Ben Salem, L., 2005a. Effect of early experience and adaptation period on voluntary intake, digestion, and growth in Barbarine lambs given tannin-containing (Acacia cyanophylla Lindl. Foliage) or tanninfree (Oaten hay) diets. J. Anim. Feed Sci. Technol. 122, 59-77.

Ben Salem, H., Smith, T., 2006. Feeding strategies to increase small ruminant production in dry environments. Small Rumin. Res. 77, 174-194.

Brown, D., Ngambi, J. W., Norris, D., 2017. Effect 
of tanniniferous Acacia karroo leaf meal inclusion level on feed intake, digestibility and live weight gain of goats fed a Setaria verticillata grass hay-based diet. J. Appl. Anim. Res. 46(1), 248-253.

Carro, M. D., Cantalapiedra-Hijar, G., Ranilla, M. J., Molina-Alcaide, E., 2012. Urinary excretion of purine derivatives, microbial protein synthesis, nitrogen use, and ruminal fermentation in sheep and goats fed diets of different quality J. Anim. Sci. 90, 3963-3972.

Cheeke, P. R., 2000. Actual and potential applications of Yucca schidigera and Quilla jasponaria saponins in human and animal nutrition. J. Anim. Sci. 77, 1-10.

Cloete, S. W. P., de Villiers, T. T., Kritzinger, N. M., 1983. The effect of ammoniation by urea on the nutritive value of wheat straw for sheep. S. Afr. Tydskr. Veek. 13(3), 143-146.

Coles, E. H., 1986. Veterinary Clinical Pathology. $4^{\text {th }}$ Edn. Sunders W. B. Co., Philadelphia, London.

Conway, E. J., O'Mally, E., 1957. Production of volatile fatty acids in the rumen: Methods of measurement. Nutr. Abstr. Rev. 34, 339-352.

Domingue, B. M. F., Dellow, D. W., Barry, T. N., 1991. Voluntary intake and rumen digestion of low-quality roughage by goats and sheep. J. Agric. Sci. 117, 111-120.

Doumas, B. T., Watson, W. A., Biggs, H. G., 1971. Albumin standards and the measurement of serum albumin with bromcresol green. Clin. Chem. Acta. 31, 87-96.

Duncan, D. B., 1955. Multiple range and multiple F- test. Biometrics. 11, 1-42.

Egea, A. V., Allegretti, L. I., Paez Lama, S. A., Grilli, D. J., Fucili, M., Guevara, J. C., Villalba, J. J., 2016. Diet mixing and condensed tannins help explain foraging preferences by Creole goats facing the physical and chemical diversity of native woody plants in the central Monte desert (Argentina). Anim. Feed Sci. Technol. 215, 4757.

Eissa, M. M., El-Wakeel, El. A., Saber, A. M., Khattab, A. R., Sadek, W. M. A., 2015a. Response of Barki lambs to diets containing Cassava and treated wheat straw with Prosopis or Acacia saligna (leaves \& twigs) under semiarid area in Egypt. Egypt. J. Anim. Prod. 52(4), 79.

Eissa, M. M., Sadek, W. M. A., Khattab, A. R., ElWakeel, El. A., Saber, A. M., 2015b. Impact of feeding different combination of some fodder trees and treated crop residues on Barki lambs performance under semi-arid area in Egypt. Egypt. J. Anim. Prod. 52(4), 69.

Eissa, M. M., Sadek, W. M. A., Khattab, A. R., Mohamed, H. G., 2016. Effects of feeding cassava or prosopis and their mixture along with ammoniated wheat straw on methane production (in vitro) and growth performance of growing Barki lambs under semi-arid condition. J. Anim. Poult. Prod. 7 (4), 129-135.

El Hag, M.G., Al Shargi, K. M., 1998. Comparative performance of goats and sheep fed on highfiber pelleted diets supplemented with different nitrogen sources. J. Appl. Anim. Res. 13, 179184.

El Shaer, H. M. (2003). Protein of halophytes as animal fodder in Egypt. Chapter from book Salt-tolerance strategy of two halophyte species: Spartina alterniflora and Suaeda fruticosa, pp.111-119.

El Shaer, H. M., 2004. Potentiality of halophytes as animal fodders under arid conditions of Egypt. In: Ferchichi A. (comp.), Ferchichi A. (collab.). Réhabilitation des pâturages et des parcours en milieux méditerranéens. Zaragoza. pp.369374.

El Shaer, H. M., 2010. Halophytes and salt-tolerant plants as potential forage for ruminants in the Near East region. Small Rumin. Res. 91, 3-12.

FAO, 1992. Food Agriculture Organization. Legume trees and other fodder trees as protein sources for livestock In: Speedy, A., Pugliese, P.L. (Eds.), Proceedings of the FAO Expert Consultation.

Fawcett, J. K., Scott, J. E., 1960. A rapid precise method for the determination of urea. J. Clin. Pathol. 13, 156-159.

Fayed, A. M., Youssef, K. M., Abou-El-Naser, H. M., 2001. Nutritional performance of goat fed non-conventional diets based on olive pulp in Sinai. Egyptian: Nutr. Feeds. 1, 81-89.

Foroughbakhch, R., Hernández-Piñero, J. L., Carrillo-Parra, A., Rocha-Estrada, A., 2013. Composition and animal preference for plants used for goat feeding in semiarid northeastern México. J. Anim. Plant Sci. 23(4), 1034-1040.

Fulkerson, W. J., Horadagoda, A., Neal, J. S., Barchia, I., Nandra, K. S., 2008. Nutritive value of forage species grown in the warm temperate climate of Australia for dairy cows: Herbs and grain crops. Livest. Sci. 114, 75-83. 
Gemeda, B. S., Hassen, A., 2015. Effect of tannin and species variation on in vitro digestibility, gas, and methane production of tropical browse plants. Asian Austral. J. Anim. Sci. 28(2), 188-199.

Gornal, A. C., Bardawill, C. J., David, M. M., 1949. Kit protein Egyptian American Co. for laboratory services. J. Biol. Chem. 177, 751-755.

Horton, G. M. J., 1981. Composition and digestibility of cell wall components in cereal straws after treatment with anhydrous ammonia. Cart. J. Anim. Sci. 61, 10-59.

Kaneko, J. J., 1989. Clinical Biochemistry of Domestic Animals. $4^{\text {th }}$ Edn. Academic Press.

Klita, P.T., Mathison, G. W., Fenton, T. W., Hardin, R. T., 1996. Effects of alfalfa root saponins on digestive function in sheep. J. Anim. Sci. 74, 1144-1156.

Lowry, J. B., 1990. Toxic factors and problems: Methods of alleviating them in animals. In: Shrubs and Tree Fodders for Farm Animals (Ed.: C. Devendra). Proceedings of a Workshop in Denpasar, Indonesia. IDRC, Ottawa, Canada. 76p.

Mahmoud, H. A., 2001. Physiological and nutritional studies on sheep feeding certain halophytic plants in Sinai. M.Sc. Thesis, Faculty of Science, Cairo University, Giza, Egypt.

Makkar, H. P. S., 2003. Effects and fate of tannins in ruminant animals, adaptation to tannins, and strategies to overcome detrimental effects of feeding tannin-rich feeds. Small Rumin. Res. 49, 241-256.

Mau, M., Müller, C., Langbein, J., Rehfeldt, C., Hildebrandt, J. P., Kaiser, T. M., 2006. Adhesion of bovine and goat salivary proteins to dental enamel and silicate Arch. Tierz. Dummerst. 49(5), 439-446.

Mc Sweeney, C. S., Palmer, B., McNeill, D. M., Krause, D. O., 2001. Microbial interactions with tannins: Nutritional consequences for ruminants. Anim. Feed Sci. Technol. 91, 83-93.

Mehrez, A. Z., Mousa, M. R. M., El-Shabrawy, H. M., 2011. Effect of feeding varying levels of acacia leaves and twigs on productive performance of Awassi Ewes under Semi-arid conditions of north Sinai. Egypt. J. Nutr. Feeds. 14 (1), 39-52.

Min, B.R., Barry, T. N., Attwood, G. T., Mcnabb, W. C., 2003. The effect of condensed tannins on the nutritive and health of ruminants fed fresh temperate forages: A review. Anim. Feed Sci. Technol. 106(1-4), 3-19.

Mlambo, V., Marume, U., Gajana, C. S., 2015. Utility of the browser's behavioural and physiological strategies in coping with dietary tannins: Are exogenous tannin inactivating treatments necessary. South Afr. J. Anim. Sci. 45(5), 441-451.

Moujahed, N., Ben Salem, H., Kayouli, C., 2005. Effects of frequency of polyethylene glycol and protein supplementation on intake and digestion of Acacia cyanophylla Lindl. foliage fed to sheep and goats. Small Rumin. Res. 56, 65-73.

Mousa, M. R. M., El-Shabrawy, H. M., 2003. Growth performance of Damascus kids as affected by feeding system under Semi-arid conditions of North Sinai. J. Agric. Sci. Mansoura Univ. 28(7), 5224-5237.

Mueller-Harvey, I., 2006. Unravelling the conundrum of tannins in animal nutrition and health. J. Sci. Food Agric. 86, 2010-2037.

Muller, H. M., Leinmuller, E., Rittner, U., 1989. Effect of tanniferous plant material on protein and carbohydrate degradation in rumen fluid in vitro. In Recent Advance of Researchc in Antinutritional Factors in Lequme Seeds (Eds.: Huisman, J., Van der Poel, T. F. B., Liener, I. E.), Wageningen, pp. 156- 159 .

Narjisse, H., Elhonsaali, M. A., Olsen, J. D., 1995. Effect of oak (Quercus ilex) tannins on digestion and nitrogen balance in sheep and goats. Small Rum. Res. 18, 201-206.

Ndemanisho, E. E., Mtenga, L. A., Kimbi, E. F. C., Kimambo, A. E., Mtengati, E. J., 1997. Substitution of dry Leucaena leucocephala (DLL) for cotton seed cake (CSC) as a protein supplement to urea treated maize stover fed to dairy weaner goats. Anim. Feed Sci. Technol. 73, 365-374.

Nefzaoui, A., Ben Salem, H., Abdouli, H., Ferchichi, H., 1993. Palatability of some Mediterranean shrubs. Comparison between browsing time and bacteria technique. In: FAO/CIHEAM Workshop on Sheep and Goats Nutrition, Thessaloniki, Greece, pp.99-109.

NRC, 1985. Nutrient requirements of domestic animals. Nutrient requirements of sheep. National Research Council, Washington. Pearson D. Chemical Analysis of Foods. $7^{\text {th }}$ Edn. Livingstone, London, pp.7-11.

Ortiz, L. T., Centeno, C., Tervino, J., 1993. Tannins 
in faba bean seeds: Effect on the digestion of protein and amino acids in growing chicks. Anim. Feed Sci. Technol. 41, 271- 278.

Oshodi, A. A., 1992. Proximate composition, nutritionally valuable minerals and functional properties of Adenopus breviflorus Benth. seed flour and protein concentrate. Food Chem. 45, 79-83.

Patra, A. K., Sharma, K., Dutta, N., Pattanaik, A. K., 2002. Effect of partial replacement of dietary protein by a leaf meal mixture containing Leucaena leucocephala, Morus alba and Azadirachta indica on performance of goats. Asian-Aust. J. Anim. Sci. 5(12), 17321737.

Pearson, D., 1976. Chemical Analysis of Foods. $7^{\text {th }}$ Edn., Churchill Livingstone, London, UK, pp.72-73, 138-143, 488-496.

Reed, J. D., Soller, H., Woodward, A., 1990. Fodder tree and straw diets for sheep: Intake, growth, digestibility and the effects of phenolics on nitrogen utilization. Anim. Feed Sci. Technol. 30, 39-50.

Reitman, S. M. D., Frankel, S., 1957. A colorimeter method for determination of serum glutamic oxaloacetic acid and glutamic pyruvic acid transferees. Am. J. Clin. Path. 28, 56-63.

Robertshaw, D., 1982. Effects of college attendance on locus of control. J. Personal. Soc. Psychol. 43(4), 802-810.

Rogosic, J., Pfister, J. A., Provenza, F. D., Grbesa, D., 2006. Sheep and goat preference for and Rome, Italy, pp.32-93.

Salem, A. F. Z. M., 2005. Impact of season of harvest on in vitro gas production and dry matter degradability of Acacia saligna leaves with inoculum from three ruminant species. Anim. Feed Sci. Technol. 123, 67-79.

Salem, A., Salem, M., El-Adawya, M., Robinson, P., 2006. Nutritive evaluations of some browse tree foliages during the dry season: Secondary compounds, feed intake and in vivo digestibility in sheep and goats. Anim. Feed Sci. Technol. 127, 251-267.

Santra, A., Karim, S. A., Mishra, A. S., Chaturvedi, O. H., Prasad, R., 1998. Rumen ciliate protozoa and fiber utilization in sheep and goats. Small Rumin. Res. 30, 13-18.

SAS Institute, 2003. SAS/STATR User's Guide: Statistics. Ver. 9.1, SAS Institute Inc., Cary, NC, USA.

Schirmeister, J., Willmann, H., Kiefer, H.,
Hallauer, W., 1964. Fuer und wider die brauchbarkeit der endogenen hrea tininclearance der fanktionellen nierendiagnostik. Dtsch. Med. Woschr. 89(9), 1640-1647.

Shaker, Y. M., Abou El-Ezz, S. S., Hashem, A. L., 2008. Physiological performance of Barki male lambs fed halophytes under semi-arid conditions. J. Agric. Sci. Mansoura Univ. 33(9), 6393-6408.

Shaker, Y. M., Ibrahim, N. H., Younis, F. E., El Shaer, H. M., 2014. Effect of feeding some salt tolerant fodder shrubs mixture on physiological performance of Shami goats in southern Sinai, Egypt. J. Amer. Sci. 10(2s), 6677.

Silanikove, N., 2000. The physiological basis of adaptation in goats to harsh environments. Small Rumin. Res. 35(6), 181-193.

Silanikove, N., Gilboa, N., Nir, I., Perevolotsky, A., Nitsan, Z., 1996. Effect of a daily supplementation of polyethylene glycol on intake and digestion of tannin-containing leaves (Quercus calliprinos, Pisticia lentiscus and Ceratonia siliqua) by goats. J. Agric. Food Chem. 44, 199-205.

Soliman, A. A. M., Ahmed, M. E., AbouAmmou, F. F., Shehata, E. I., Abou-Elmagd, M. K., Tawfik, S. A., Shebl, M. A., 2010. Impact of some feed additives on Zaraibi goats performance and blood profile fed aflatoxin contaminated diets. Amer. Euras. J. Agric. Environ. Sci. 7(1), 80-88.

Streeter, M. N., Hill, G. M., Wagner, D. G., Owens, F. N., Hibberd, C. A., 1993. Effect of bird resistant and non bird resistant sorghum gain on amino acid digestion by beef heifers. J. Anim. Sci. 71, 1648-1656.

Szumacher-Strabel, M., Cieślak, A., 2010. Potential of phytofactors to mitigate rumen ammonia and methane production. J. Anim. Feed Sci. 19, 319-337.

Tietz, N. W., 1987. Textbook of Clinical Chemistry. W. B. Saunders Co. London, Philadelphia, $796 \mathrm{p}$.

Topps, J. H., 1992. Potential, composition and use of legume shrubs and trees as fodder for livestock in the tropics. J. Agric. Sci. Camb. 118, 1-8.

Van Soest, P. J., 1991. Symposium of factors influencing the voluntary intake in relation to chemical composition and digestibility. J. Anim. Sci. 24, 834-843. 
Wang, Y., Mc Allister, T. A., Newbold, C. J., Rode, L. M., Cheeke, P. R., Cheng, K. J., 1998. Effects of Yucca schidigera extract on fermentation and degradation of steroidal saponins in the rumen simulation technique (RUSITEC). Anim. Feed Sci. Technol. 74, 143153.

Warner, A. C. I., 1964. Production of volatile fatty acids in the rumen: Methods of measurements. Nutr. Abstr. Rev. 34, 339-352.

Yusran, M. A., Teleni, E., 2000. The effect of a mix of shrub legumes supplement on the reproductive performance of Pernankan Ongole cows on dryland smallholder farms in Indonesia. Asian-Aus. J. Anim. Sci. Suppl. (Vol. A) 13, 481.

\section{How to cite this article:}

Sadek, W. M. A., Elwakeel, E. A., Saber, A. M., Abdel-Mawla, L. F., Anwar, M. M., Ghobashy, H., Eissa, M. M., 2020. Comparative study of tanniniferous shrubs as an alternative source of feed on performance of sheep vs. goats under semi-desert conditions of the north western-coast of Egypt. Int. J. Curr. Res. Biosci. Plant Biol. 7(3), 1-14. doi: https://doi.org/10.20546/ijcrbp.2020.703.001 